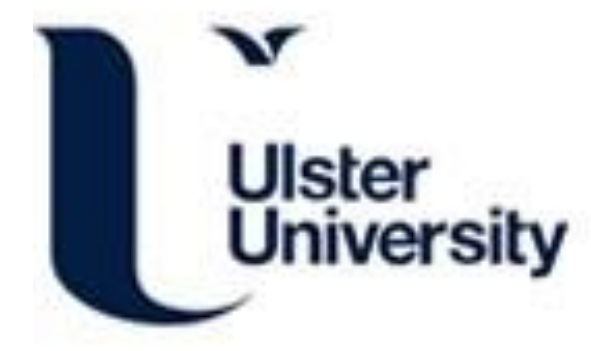

\title{
Analysing Housing Market Affordability in Northern Ireland: towards a better understanding
}

McCord, M., Davis, P., Haran, M., \& McCord, J. (2016). Analysing Housing Market Affordability in Northern Ireland: towards a better understanding. International Journal of Housing Markets and Analysis, 9(4), 554-579. https://doi.org/10.1108/JJHMA-09-2015-0054

Link to publication record in Ulster University Research Portal

\section{Published in:}

International Journal of Housing Markets and Analysis

Publication Status:

Published (in print/issue): 03/10/2016

DOI:

10.1108/IJHMA-09-2015-0054

\section{Document Version}

Author Accepted version

\section{General rights}

Copyright for the publications made accessible via Ulster University's Research Portal is retained by the author(s) and / or other copyright owners and it is a condition of accessing these publications that users recognise and abide by the legal requirements associated with these rights.

\section{Take down policy}

The Research Portal is Ulster University's institutional repository that provides access to Ulster's research outputs. Every effort has been made to ensure that content in the Research Portal does not infringe any person's rights, or applicable UK laws. If you discover content in the Research Portal that you believe breaches copyright or violates any law, please contact pure-support@ulster.ac.uk. 


\section{Inereald}

\section{Analysing Housing Market Affordability in Northern Ireland: towards a better understanding?}

\begin{tabular}{|r|l|}
\hline Journal: & International Journal of Housing Markets and Analysis \\
\hline Manuscript ID & IJHMA-09-2015-0054.R1 \\
\hline Manuscript Type: & Research Paper \\
\hline Keywords: & $\begin{array}{l}\text { Housing affordability, Housing policy, principal component analysis, } \\
\text { Johansen Cointegration, Impulse response, Granger causality }\end{array}$ \\
\hline \multicolumn{2}{|c}{} \\
\hline
\end{tabular}




\title{
Analysing Housing Market Affordability in Northern Ireland: towards a better understanding?
}

\begin{abstract}
Purpose: Although the problem of housing affordability has been widely discussed, the theoretical underpinnings of the concept have received less attention. It has become increasingly evident that more holistic insights and integrated approaches are needed to provide a platform to define affordability, in order to influence research and policy discourse.

Design/methodology/approach: Given the increasing importance of affordability within housing policy reform, this paper seeks to 'unearth' the most important prognosticators of affordability. The paper employs principal component analysis to determine how affordability, as a key policy tool, should be analysed. In addition, cointegration techniques, Granger causality and impulse response analysis are applied to test the movement and shocks of the key affordability indicators and two common affordability metrics.

Findings: The principal conclusions stemming from this paper demonstrate that affordability is a multifaceted policy concept influenced by financial access (purchase) costs and the repayment costs of housing services which are correlated and interchangeable, but significantly were found not to be cointegrated.

Originality/value: Understanding the nature of housing market affordability remains problem for policy makers. This paper adds to the debate and empirical understanding of the cyclic nature of affordability and how it is defined. It shows that there are intricate causal short-term relationships between the key affordability indicators. This is problematic for contemporary housing policy and the key directions in which policy must turn.
\end{abstract}

Keywords: Housing affordability, housing policy, principal component analysis, Johansen Cointegration, Impulse response, Granger causality.

\section{Introduction}

The readjustment in the global financial landscape since 2007 has culminated in pronounced instability and upheaval in financial and economic markets throughout most advanced economies. In the UK context, the once sanguine confidence and trust within financial markets sculpted the cornerstones of economic and housing market activity. However, the protracted aftermath of the 2007 financial crisis left the economy precariously balanced, mortgage liquidity constrained. In addition, the marked correction in the housing markets resulted in a series of exigent outcomes for home-owners, who on the back of government policy were encouraged to strive for a greater and more prosperous quality of life via the housing market. Although market recovery is evident within the UK since 2011, the transmission across the UK over the past four years has remained uneven, patchy and challenging. Indeed, key universal (top-down) housing policy decisions and macro-prudential tools have served to reinvigorate and 'heat up' the market in Southern England resulting in approximately $12 \%$ growth in 2014. This has not fully translated in other regional jurisdictions and serves to constrain access to housing and overall housing affordability pressures. 
The housing system is complex and intrinsically linked to almost every area of government policy. There is widespread recognition that the current dysfunctionality endemic within the housing system is creating significant issues for sustainable and effective policy implementation. Pertinently, the dysfunction within these market dynamics has cemented the affordability debate firmly within the confines of both social and economic policy. Indeed, this scale and complexity has resulted in a disparate set of housing policies which tend to focus on one particular aspect and thus fail to capture the wider context, leaving policy largely fractured and convoluted.

Although the term affordability has been in widespread use since the 1960s, at the international level, understanding housing market affordability remains nebulous and 'vexed' (Wilcox, 1999). As far back as the early 1990s, Whitehead (1991) identified a lack of analytical clarity in relation to the concept of affordability. Two decades on, this issue still has resonance within contemporary policy debate. Nonetheless, even with an ongoing policy narrative surrounding the issue of affordability, progress in addressing the term has been limited (Burke, 2001). It has proved difficult to secure agreement surrounding the right mix of housing policy within government and how best to address it is a matter of considerable contention (Gabriel et al., 2006). This is highlighted by Gan and Hill (2009) who identify that the theoretical underpinnings of the concept have received relatively little attention. In addition, ongoing debate surrounds the conventional measures of affordability, which are perceived to be narrowly conceived and merely serve to emphasise 'particular' aspects of housing market affordability. These complexities are further compounded by the problem that different sectors of society can be differentially affected by market movements (Gan and Hill, 2009). As a result, affordability is ambiguous and resists simple definition, contributing to limited understanding concerning the relationships and variable subset which constitute it (Gabriel et al., 2006).

It is becoming increasingly evident that a more in-depth understanding is required in order to guide research and influence policy discourse. The identification of the dimensions and most important indicators of affordability is imperative, as the ineffectiveness of affordability policy has a complex set of institutional and economic causes (Rosen and Ross 2000; Yang and Shen, 2008). In this regard, this paper is designed to address and define housing affordability through the examination of the underlying issues which cause disequilibrium within housing markets. The paper links the theoretical discussion of measuring affordability to the wider discussions surrounding the somewhat arcane nature of the property market and the impacts for fruitful policy implementation. It seeks to advance the understanding and conceptualisation of affordability and contribute to the existing body of affordability literature. The paper highlights the underlying constructs of affordability which helps to further analyse and conceptualise affordability interpretation and aid policy discourse.

Differing approaches to measuring affordability 
There is limited consensus about what housing affordability means (Abelson, 2009). In a generic sense Milligan et al. (2004) observe affordable housing to be housing which assists lower income households in obtaining and paying for appropriate housing without experiencing undue financial hardship. Much of the debate pivots on pervasive definitional uncertainty and problematic measures, epitomised by Trans-Atlantic and international divergence between the main approaches to defining affordability. The US and Canadian perspective observe housing affordability to be a repayment issue relating to housing costs and the servicing of debt. In other jurisdictions such as the U.K., particular focus is placed on lower income households with affordability defined as the ratio of lower quartile house price to incomes similar to studies of Zhang (2007) and Zhou et al. (2010). This approach centres on access to the market, and not entirely income affordability as this is considered of little relevance for cohorts already in situ within the mainstream housing market. A weakness of the house price-income ratio is that it ignores the cost of housing finance and neglects to indicate the capacity to repay ongoing housing costs. Milligan (2003) suggests that the residual incomes of households after they have met their housing costs provide a much more direct measure of household financial resources, as the ratio approach disregards the costs associated with continued ownership, thus neglecting the costs associated with life-cycle affordability. This argument is supported by Burke et al. (2004) who caution that the use of constant lending practices over time neglects to capture the reality of lending practices in the market.

Nonetheless, there has also been extensive criticism of definitions which focus on housing costs and the arbitrary effects upon income, to the exclusion of other factors such as the ability to borrow and the interaction of planning and social policy (Freeman et al., 2000). Mulliner and Maliene (2015) perceive housing affordability to be multi-dimensional concept, however emphasise that the scope has frequently been narrowed down to focus on the financial aspect. This is in accordance with the work of Chai and Lu (2015) who perceive affordability to be in conjunction with three other dimensions of accessibility, amenity and adequacy which widen the scope beyond those previously restricted to pricing and income. Such criticism was originally discussed by Linneman and Megbolugbe (1992) who argue that monthly home-owner costs may present a misleading measurement and that the true measure for home-owners is the user cost, which includes expected appreciation in capital value. On a different note, Marks and Sedgwick (2008) contend that applying normative judgements of housing costs in excess of 30 per cent of household income is specious and more dependent on equivalised disposable income. Previous work by Hancock (1993) suggests that using the residual approach masks an acceptable opportunity-cost which is being consumed, claiming that it makes little sense to define affordability in terms of the ratio of housing costs to incomes if it is believed that opportunity-cost is important. Subsequently, Hancock (1993) further indicates that, within the ratio explanation, it is possible to consume very little of either housing or other goods and for housing costs still to be considered. This is substantiated by the perspective from New Zealand (HNZC, 2004) which argues that affordability is not merely a calculation of housing costs and income, rather it is the ability to obtain housing and to maintain homeownership, but also have sufficient residual income to purchase basic consumerables. This residual continuous cost is identified by Kutty (2007) 
who suggests that for owner-occupiers, changes in affordability are primarily related to amendments in mortgage costs.

Abelson (2009) extends the debate by introducing the idea of measuring 'the deposit gap': the measurement of borrowing affordability which illustrates what households can realistically borrow relative to the value of the average property. This concept is under researched within affordability literature, however it remains an important prognosticator in the contemporaneous housing market. Pertinently, Abelson (2009) declares that the difference between the price of a typical dwelling and the maximum loan that could be repaid from average household income, expressed as a proportion of that income, is an accurate measure of affordability. The theoretical literature highlights that although considerable debate exists amongst housing professionals and researchers on the issue of affordability, a significant number have opted to measure affordability by expressing housing costs as a share of net household income. Indeed, this has fuelled further debate surrounding the appropriate definition of affordability, and the actual share of income which households should be expected to realistically expend on housing costs. This cannot be achieved objectively, and therefore, normative decisions are essential for analysis. This lack of a clear definition makes it somewhat difficult to accurately classify at what point affordability requires intervention.

There are also concerns expressed in scholarly literature regarding the utility of ratio measures in adequately capturing the full extent of housing affordability, and the influence of these measures within the policy arena. In market upswings, increased house prices are excluding lower income cohorts from accessing the private housing market, culminating in a deterioration of affordability conditions. However, this assumption is based upon one aspect of purchase affordability. Simultaneously, It could be argued that this one sided perspective neglects to account for capital gains, which for existing home-owners actually increases affordability, thus, creating significant issues of social disparity and exclusion within the housing system. Repayment affordability indicates that in times of house price decline, housing should effectively be more affordable, as the income to house price ratio would be decreased. Recent events in the capital markets however have shown that this is not always the case and availability of finance within the mortgage market is the most pressing measure. These more recent concerns pivot on purchase affordability and primarily the 'ability to borrow' as a consequence of significant deposit levels and enlarged borrowing costs of capital (McCord et al., 2011). It is clearly problematic in a policy context to apply one approach in favour of another when seeking to analyse affordability. Gan and Hill (2009) emphasise that focus on the traditional ratio and residual affordability approaches neglect issues of access or purchase affordability which can have serious policy ramifications. To that end, all measures classify housing affordability to be the personal troubles experienced by individual households, both in accessing the market and the sensitivity to market fluctuation.

Bramley and Karley (2005) suggest a way forward from this debate is to merge these two paradigms as they are mutually exclusive. Indeed, they propose that a household's circumstances are 'unaffordable' if they face both a ratio of housing cost to income above 
certain norms and a ratio of residual income to household requirements which is below certain other norms. This builds upon Chaplin et al. (1994), who argue that a combined approach should be used for measurement and conceptualising affordability, as each measure provides a different perspective to the fundamental interplay between market indicators. Furthermore, they deem the two measures to be complementary, in that they provide relative strengths. In contrast, Whitehead (1991) errs on the side of caution, suggesting that there are difficulties in interpreting the two measures concurrently, as results of the two conclusions can manifest in conflicting policy discourse. Nonetheless, Katz et al. (2003) suggest that mixed approaches to analysing housing affordability are required. This was a similar conclusion to that of Pomerov (2004) who stated that analysis of the demand side alone would not address the lack of new supply that is the reason behind rising prices and deteriorating affordability. More recently Haffner and Heylen (2011) have advocated for a more comprehensive approach to affordability, which intertwines the short-term access costs with the long-term costs of housing services, illustrating that they should be used 'in synch' to present an overall picture of affordability. Indeed, Haffner and Heylen (2011) suggest that the two applied affordability approaches complement one another but are not interchangeable. Moreover, they suggest that this affords further analysis of the complex interplay of variables that influence affordability. This is in tandem with the work of McCord et al. (2011) who suggested that housing market affordability should be analysed carefully, as the way it is measured can result in it being misinterpreted. They also draw attention to the reality that the changing nature of affordability within the market cycle can proliferate different aspects and indicators of what makes the housing market unaffordable at different times, further complicating an already complex situation.

Given the existing literature offers some debate as to the way affordability should be measured and applied, and that it is not a one-dimensional concept, and that a combination of more than one concept provides a better understanding of affordability (Haffner and Heylen, 2011), this research proceeds to measure the relationship between the key indicators which constitute affordability and measure the integrated aspects between both the traditional house price to income concept and a more novel ability to repay measure within the Northern Ireland jurisdiction. In doing so, this tests the interchangeability of affordability concepts and indeed the underlying interaction between the indicators.

\section{Research Data and Methodology}

Data

To examine the interrelationships between the indicators and two affordability concepts, the data is derived from a number of robust national and regional governmental and institutional sources pertaining to Northern Ireland (Table 1), covering the period 1993 to 2010 (quarterly). The data pertaining to lending and borrowing is derived from the Council of Mortgage Lenders (CML) which comprises of banks, building societies and specialist lenders serving to represent $98 \%$ of mortgages. The income data is derived from the Annual Survey for Hours and Earnings (ASHE) a NI regional governmental source which operates 
under the umbrella of the Office of National Statistics. The average lower quartile house price is obtained from the University of Ulster House Price Index ${ }^{1}$. This survey analyses the performance of Northern Ireland house prices quarterly and is based on a large and representative sample size of open market transactions. Data relating to mortgage interest rates (MIR) were derived from the Bank of England statistical interactive database. The weighted average interest rates were applied as they represent the 'typical' buyer mortgage agreement. In addition, the User cost of housing was calculated using the user cost formula proposed by Poterba (1992) which indicates that:

$$
\text { User cost of housing }=P\left(i^{\mathrm{a}}+\tau+f-\pi\right)
$$

where $P$ is the house price, $i^{a}$ is the after-tax mortgage interest rate, adjusted to encompass the period of tax deduction through mortgage interest relief (MIRAS) which applied between the period 1993 and 2000. This calculation accounts for deduction ceilings or credits and the tax base against which the deduction is applied. $\tau$ signifies the property tax rate for owner-occupation which has been calculated using the horizontal spread across the jurisdictional tax rate for Northern Ireland, $f$ represents recurrent housing costs comprising depreciation, maintenance and associated operating costs. $\pi$ is the expected capital gains or loss which is taken as the lagged change in house price per annum as there is no capital gains tax on principal private residences in NI, thus denoting expected future house price inflation.

$<$ Table 1 $>$ Data Source and Description

\section{Principal Component Analysis}

To investigate and analyse the interaction and interrelationships between the indicators this paper employs multivariate techniques. These techniques investigate the possible patterns which exist in data-sets, enabling composite inter-relationships to be represented, and provide a mechanism for reducing the dimensionality of data for further analysis. Principal component analysis (PCA) is one of the most established and best known of the techniques of multivariate analysis (Jolliffe, 1986). The essence of the approach is to calculate the eigenvalue decomposition (spectral decomposition), which is the factorisation of a matrix into a canonical state, of which the results are expressed as scores and loadings, thereby decomposing an original dataset into a set of linear variates (Field, 2009). PCA is only concerned with the establishment of linear components which exist within the data, emphasising the contribution a specific variable makes to a component. Components are derived directly from the correlation matrix, which explains all the variance held within the matrix (Kline, 1994). Hence, PCA maximises the variance (sum of the squared loadings)

\footnotetext{
${ }^{1}$ Provided by the Centre for Research on Property and Planning in partnership with Bank of Ireland and the Northern Ireland Housing Executive (N.I.H.E)
} 
explained for any number of factors and detects a structure in the relationships between the variables. This technique requires that the correlation matrix $R=\left\{R\left[R_{m m}\right]\right\}$ is obtained through the transformation of the data matrix $\mathrm{X}=\{\mathrm{X}[\mathrm{mn}]\}$ into a matrix of standardised scores $[Z]$ which are computed using the mean and standard deviation for each row $m$ of the data matrix where $m$ is the number of elements (variables) and $n$ is the number of observations (column vectors) in the dataset. This is represented by the following formula:

$$
\mathrm{Y}^{\mathrm{T}}=\mathrm{X}^{\mathrm{T}} \mathrm{W}=\mathrm{V} \sum^{\mathrm{T}}
$$

Where the matrix $\Sigma$ is a diagonal $[m \times \mathrm{x} n]$ matrix with non-negative real numbers on the diagonal and $\mathrm{W} \Sigma \mathrm{V}^{\mathrm{T}}$ is the singular value decomposition of $\mathrm{X}$. The factor scores $\left[\mathrm{S}_{\mathrm{np}}\right]$ for the original $n$ observation, on each $p$ component are calculated by the following:

$$
\mathrm{S}_{\mathrm{np}}=\left(\mathrm{Z}_{\mathrm{mn}} \times \mathrm{L}_{\mathrm{pm}}^{\mathrm{T}}\right)
$$

The variance is equal to the trace of the matrix, the sum of the diagonals, or the number of observed variables in the analysis, minimising the sum of the squared perpendicular distance to the component axis (Truxillo, 2003). To identify the number of Principal Components (PCs) to be retained, the analysis applies a prior criterion in order to select the number of PCs that explains the maximum amount of variance. The eigenvalue criteria of $=>1$ along with the Scree test, and the interpretability of each component was applied. Variables with absolute scoring coefficients $>0.4$ were considered important contributors to a pattern, a logic premised on Steven's (2002) suggestion that loadings greater than 0.4 represent substantive values which are appropriate for interpretative purposes. The Varimax rotation method with Kaiser Normalization is applied in order to furnish the most accurate and reliable inferences within the data.

\section{Cointegration Modelling}

To analyse whether the indicators and affordability measures are co-integrated over time, the Johansen (1991) procedure ${ }^{2}$ is applied based on the vector-autoregressive (VAR) specification. The testing procedure is carried out in two phases: (1) testing for the level of integration and stationary to ensure that the data is integrated of the same order and (2) to estimate the "cointegrating equation," and test whether the residual (errors) of the model is stationary. This ensures that the model defines a long-run equilibrium relationship among the cointegrated variables. The first step of testing cointegration is to test all the time series variables for stationarity. Therefore, the augmented Dickey-Fuller (ADF) unit root test is conducted on each of the data series in order to verify the level of integrated order $^{3}$ and to transform the data to covariance stationary. As the data is quarterly, this research applies an initial lag specification of $(2,4)$ for correction of autocorrelation. The unit root test of levels includes intercept and also time trend as the data is trended.

\footnotetext{
${ }^{2}$ For a full discussion of the Johansen approach see Johansen, S (1991) Estimating and testing cointegration vectors in Gaussian vector autoregressive models, Econometrica, Vol. 59, pp. 1551-1580.

${ }^{3}$ There are several tests for testing the unit root (Phillips-Perron; Kwitkowski et al. (KPSS); Elliott et al. (ERS))
} 
The Johansen test provides estimates of all such cointegrating equations and provides a test statistic for the number of cointegrating equations (vectors) ${ }^{4}$. In the Johansen procedure two test statistics, the trace statistic and the maximum eigenvalue statistic are produced to assess whether cointegration exists. The trace statistic tests the null hypothesis: 'there are at most $r$ cointegrating relations' against the alternative of $m$ cointegrating relations; the series are stationary where $r=0,1, \ldots . m-1$. The maximum eigenvalue tests the null hypothesis: 'there are $r$ cointegrating relations' against the alternative: 'there are $r+1$ cointegrating relations'. The deterministic trend in the VAR and cointegrating equations is selected based on the level of trending assumption. The specification of VEC model comprises the cointegration equations evidenced from the Johansen testing. This error correction approach allows for short-run adjustment dynamics and also the convergence towards long-run relationships. The VEC (for 1 cointegrating equation $(y=\beta x)$ and one lag of difference terms can be identified as:

$$
\begin{aligned}
& \Delta x_{t}=\alpha_{1}\left(y_{t-1}-\beta x_{t-1}\right)+y_{11} \Delta x_{t-1}+y_{12} \Delta y_{t-1}+\varepsilon_{1 t} \\
& \Delta y_{t}=\alpha_{2}\left(y_{t-1}-\beta x_{t-1}\right)+y_{21} \Delta x_{t-1}+y_{22} \Delta y_{t-1}+\varepsilon_{2 t}
\end{aligned}
$$

The interpretation of VAR models based on parameter matrices $A_{1}, \ldots, A_{p}$ is clearly restricted. Therefore Impulse response functions are used to examine the reaction of every single variable in the model on an exogenous shock (impulse) to the model. The reaction is measured over the specified periods after shocking the system. The impulse response analysis is therefore a tool for inspecting the inter-relation of the model variables as the impulse response function traces the effect of a one-time shock to one of the innovations on current and future values of the endogenous variables.

\section{PCA Findings}

The principal component analysis was conducted on the variables using a Varimax orthogonal rotation method. The Kaiser-Meyer-Olkin measure verified the sampling accuracy of the data, $\mathrm{KMO}=.701$, with all $\mathrm{KMO}$ values above the minimum acceptable threshold of .04 (in accordance with Stevens, 2002). Bartlett's test of sphericity $\chi^{2}(21)=$ $633.95, \mathrm{p}<.001$, indicates that correlations between the variables were sufficiently large for PCA and indicates that the $R$-matrix is not an identity matrix. Overall, both tests revealed that PCA is appropriate for the data. The PCA analysis retained two components with eigenvalues greater than one which cumulatively explain $88.87 \%$ of the total variance in the original seven variables (Table 3). Overall, the extracted and rotated sums of squared loadings indicate that two underlying dimensions explain affordability. This is confirmed by both the component score matrix and Scree plot which suggest the retention of two components as they meet all assumptions and guidelines advanced in the criterion of extraction.

\footnotetext{
${ }^{4}$ It is a likelihood ratio test statistic that Johansen test presents along with the critical values.
} 
The first extracted component loaded positively on borrowing costs, the size of deposit required to access housing, the price of lower quartile market housing, income level, the overall user cost of housing and negatively on the availability of mortgage finance within the market, representing the 'access to the market'. This purchase affordability essentially highlights the dynamic nature of and difficulty in analysing housing market affordability; illustrating it to be an income and access issue. Indeed, this access to the market is dependent upon the borrowing capacity of a prospective household which encompass the level of income to the house price, the initial down-payment capital (deposit gap) which is apportioned by the mortgage environment and the expected user costs (inclusive of capital gains) of housing. The second component reveals a high positive loading between mortgage interests rates, borrowing costs (\% of income), and continuous user costs of housing, and negatively loaded on the LQ market price of housing and income thereby measuring what appears to be 'the ability to repay housing costs'. This component therefore infers that the cyclical movements in market pricing and income can increase or decrease user costs and the overall borrowing and repayment costs of housing:

\section{$<$ Table 2> Summary of PCA results}

The variables that cluster on the same components suggest that component one represents purchase/borrowing affordability and the initial access conditions in the market faced for first-time purchasers. Component two demonstrates a repayment affordability issue. However, the picture is slightly more complicated due to the several variables loading onto more than one factor. This has primarily occurred due to the relationship between the factors, which serves to reinforce the argument that affordability should not be analysed using one measure or approach as it is an omnipresent concern based on the inter-relationships between these coefficients within the market cycle. These findings suggest that independence between the coefficients cannot be assumed and they are interrelated across market cyclicity $(C o r r=0.8601, p<.001)$. Moreover, the findings emerging from the PCA show affordability to be complex and essentially a two tiered process relating to accessing the market and the ongoing costs of housing consumption. The findings illuminate that contentious narrative debating which existing affordability measure is superior are flawed, particularly in terms of policy making. Significantly the results are in parallel with the study conducted by Haffner and Heylen (2011) who stipulate that affordability is essentially a short-term versus longterm costs issue which requires a combination of more than one concept to offer better insight into the affordability of housing for consumers. This is also in line with Gan and Hill (2009) who disaggregated affordability into three distinct concepts of purchase, repayment and income affordability. Importantly this research, akin to Haffner and Heylen (2011), suggests that each measure of affordability is useful as it analyses the interconnected web of indicators needed to portray housing affordability. Nonetheless, they stress that they should be used in tandem to paint a more inclusive picture of the measures which supplement one another, as they are inter-connected. This is important for policy consideration when measuring affordability and for future policy development. 


\section{Affordability Indicator Interaction and Cointegration}

The prominent variables considered to shape housing affordability are further analysed to understand the long and short-term relationships between them. This is important in order to expose more granular insight to what drives housing market affordability and furnish insights into the causal and adjustment effects. The Augmented Dickey-Fuller test shows that all variables with the exception of User-cost reveal the presense of a unit root and that the data is non-stationary and does not evidence pure random walk processes. The ADF test was re-run at first differencing, eliminating autocorrelation in the residuals (Table 3) yielding rejection of the null hypothesis.

\section{<Table 3> Augmented Dickey-Fuller Unit Root Tests}

The Johansen co-integration test using a lag interval of 2 is evidenced in Table 4. The Trace test illustrates 7 cointegrating equations (error-terms). This is confirmed by the maximum eigenvalue test which illustrates 6 cointegrating equations - showing all the variables to have long-term association.

\section{$<$ Table 4> Cointegration Results between the Affordability Indicators}

\section{Vector Error Correction Model}

Given the strong evidence for cointegration and presence of error terms, a VECM is constructed to analyse both the long-run relationships and short-term speed of adjustment towards equilibrium. The ECM was initially tested for optimal lag length, with all selection criteria tests, with the exception of the Schwarz information criterion (-1) highlighting that a lag selection of 5 periods was requisite. Each error correction system equation model based on a dependent variable specification was subsequently analysed to investigate the long-term speed of adjustment. The findings show that in the coefficients of the cointegrating models (error correction terms) only one long-term causal relationship is negative and statistically significant (LTV:-8.03E-06, $p<.01$ ) (Table 5). This illustrates that there is no long-run speed of adjustment from the short-run or indeed long-run causality between the variables in general. Only, LTV demonstrates a long-run causal relationship between the variables. This is interesting as the LTV impacts on both the access and repayment affordability as supported in the PCA findings.

\section{$<$ Table 5> Long-term Causality between variables}

\section{Short-term causality}

Short-term causality for the VAR is estimated using the Wald exogeneity Test, where the Null hypothesis for example $[\mathrm{C}(2)=\mathrm{C}(3)=\mathrm{C}(4)=0]$ is that there is no short-run causality if the all the lagged terms of each independent variable collectively are equal to zero (Table 6). The findings show that none of the short-term adjustments condition house prices, however house prices do show short-run causality with deposits, income and LTV - very much driving access issues into home-ownership. In addition, there is an analogous but separate 
access issue in the short-term pertaining to the finance and lending environment. The findings reveal causal relationships between mortgage finance, LTV rates, MIRs and income.

\section{$<$ Table 6> Wald Exogeneity Test}

The Granger non-causality findings over a number of quarterly lags are evident in Table 7. The results exhibit a uni-directional relationship between house prices (HP) and borrowing costs (BC), where house prices Granger cause borrowing costs for up to 6 quarters, but not vice versa. As expected, deposit (D) requirements Granger cause BCs (6 lags), with BCs Granger causing Ds demonstrating a bi-directional relationship - albeit for two periods only. In tandem with expectation, Income (IN) uni-directionally Granger causes BC for up to 6 lags, a similar picture with mortgage finance, MIRs and the user cost of capital. The movement in HPs and D requirements reveal a bi-directional relationship, not surprising given that the fluctuation in house prices condition depository requirements. Interestingly, IN Granger causes HP (for only a lag of 2), where HPs show a significant relationship over 6 lags. This infers that an immediate change in income impacts upon house prices, with the price of housing impacting on income over the medium term. The results show a bidirectional association between LTV and HP over the 6 lags, illustrating that bank lending policy impacts on house prices, which subsequently provide a feedback loop. Again a noteworthy finding pertains to house prices and the level of mortgage finance. The results show a uni-directional relationship from HPs to MF up to 5 periods. This suggests that the movement in house prices determines (releases) mortgage liquidity but not vice versa. This is concomitant with MIRs and HPs - illustrating that the mortgage interest rate environment is Granger caused by the change in house prices and that the movement in the MIR does not drive/reduce demand for housing. Importantly, the analysis shows a bi-directional Granger causality between user cost (UC) and house prices indicating that the level of capital appreciation feeds into house prices which instantaneously feedback into the user cost.

With regards to income and deposit level there is a more complex short-term association. The level of IN Granger causes D, where D does not Granger cause IN after 2 lags but does between 3-5 periods. This suggests that income conditions deposit, with deposit level impacting on income after a period of adjustment. The findings display no uni or bidirectional Granger causality between deposit and LTVs or mortgage finance, however do reveal D to uni-directionally Granger cause MIRs. This is expected, given that elevated deposits can favour the terms of mortgage product - especially reduced interest terms. Similar to house prices, there is uni-directional Granger causality from income to both MF and LTV but not reverse causality.

\section{$<$ Table 7> Granger Causality over various lag periods}

To check each system models diagnostics for stability, the Breusch-Pagan-Godfrey test for heteroskedasticity and normality assumptions using the Jarque-Bera test were performed. The tests show no presence of heteroskedasticity $(p>.05)$ in any of the models, with the Jarque-Bera statistic and $p$-value also showing no statistical significance and acceptance of null hypothesis that the residuals are normally distributed ${ }^{5}$

\footnotetext{
${ }^{5}$ Other VAR stability tests are available upon request.
} 


\section{Existing measures Cointegration Findings}

As previously acknowledged, affordability is separately analysed as either a ratio between house prices and income or an ability to repay ${ }^{6}$. Therefore, the paper further investigates the temporal relationship and interaction between these measures. This is undertaken to test whether existing measures are 'truly' interchangeable. In this regard, the cointegration analysis further supports the results showing the long-term and short-term relationships and causal dynamics between the measures.

The ratio measure applied equates to the relationship between house prices and income (Equation 5), which is further assessed against the standard benchmark lending multiple (LM) of banking institutions eminent in Northern Ireland.

$$
\text { Ratio }=\left(L Q \frac{H P_{t}}{I n_{t}}\right) / \mathrm{LM}
$$

The repayment measure is taken as the Affordable Limit (AL) as identified by Gan and Hill (2009) which captures the ratio of the maximum allowable loan to income using an upper limit threshold premised on the maximum monthly income which can be dedicated to mortgage payment (generally 30\%). The borrowing constraint can be written as follows:

$$
\sum_{n=1}^{N}\left[\frac{\alpha X}{(1+i) n}\right] \geq \mathrm{Y}-\mathrm{D} .
$$

where $\mathrm{Y}$ is the price of a house and $\mathrm{D}$ is the deposit. This distinctively measures the effective demand borrowing capacity of a potential purchaser based on the deposit requirement (LTV), property value and mortgage interest rate and term structure. The borrowing capacity based on a stress test on the ability to service housing costs is assessed against the median property value over each period:

$$
\alpha X \geq(1-\beta) Y\left[\frac{i}{1-(1+i)^{-N}}\right] / H P_{t}
$$

\section{Affordability measures Cointegration}

Testing for a unit root enables the establishment of whether the variables are integrated of the same order and tests for stationary. Visual Inspection of the variables (Figure 1) and application the Augmented Dickey-Fuller ${ }^{7}$ procdeure shows that the two affordability measures (Ratio surplus; repayment surplus) are stationary and integrated $I(0)$; showing no

\footnotetext{
${ }^{6}$ using a threshold $30 \%$ of income based on the various macro-economic conditions/constraints, lending liquidity and income of applicants

${ }^{7}$ The ADF tests are based on visual inspection of the data time-series. Various upward trends evident and the series process not revolving around a series mean (constant), therefore the ADF test was tested for intercept and trend based on the series being assumptions of trend and constant.
} 
evidence of unit roots in the level series, therefore requires no differencing $(\mathrm{t}=-13.429$, $\mathrm{p}<.001 ; \mathrm{t}=-3.757, \mathrm{p}<.001)$. Moreover, cointegration testing reveals no long-term association between the two affordability measures, a surprising finding upon first inspection (Table 8).

$<$ Figure 1 $>$ Affordability metrics

<Table 8> Co-integration Testing of Affordability metrics

Given the existence of no cointegration, a VAR model specification (VAR(1)) was tested using a lag interval at levels (Table 9). The initial findings exhibit the coefficient to the one period repayment lag is significant in the repayment equation and just outside the $5 \%$ level of significance in the House Price-Income ratio affordability measure $(t=-1.938)$. Furthermore, the findings show that a one period lagged change in the long-term repayment measure has an influence in the contemporaneous change in repayment affordability. Observation of the one period House Price-Income ratio affordability lag is only significant in the ratio measure equation $(t=11.2893)$ and demonstrates no lagged or contemporary relationship with repayment affordability, thus the change in the long-rate ratio affordability only impacts upon the ratio measure. The VAR specification was tested to ensure that VAR(1) is satisfactory to capture the dynamics in the changes of affordability measures - if one lag is sufficient the residuals exhibit no autocorrelation. Testing the residuals for autocorrelation is performed using the Breusch-Godfrey serial correlation Lagrange multiplier test. The results of the $p$ values show that employing only one lag is not sufficient to model the dynamics, with lags of 2 and 3 more apposite. This is confirmed by further lagorder selection testing procedures applied to establish the optimal lag structure within the residuals (Table 10). The results show a lag order of 2 to be adequate.

\section{<Table 9> VAR Models}

\section{< Table 10> VAR Residual Serial Correlation LM Tests and Lag Order Selection}

Analysis of the VAR(2) model applying a lagged order of 2 shows the coefficient to the one period repayment lag is significant in the repayment equation, however the two period lag is not statistically significant. Both the one and two period lags are not significant for the House Price-Income ratio affordability measure. The House Price-Income ratio shows a one period lagged change influences the contemporaneous change in the House Price-Income measure, nonetheless, this is not significant for a lagged period of two. Pertinently, the ratio measure displays no significance with a one period lag in repayment affordability, but does appear significant $(t=2.042)$ with a two period lag which impacts upon the contemporary relationship with repayment affordability. Testing for the stability of the VAR system shows the system to be stationary. Pertinently, the root values all fall within the confines of the VAR system therefore satisfying the condition of model stability. Moreover, residual analysis also highlights that the model is satisfactory (lag $3, p>.05$ ).

\section{Wald Exogeneity and Granger Causality testing}

The short-term movement between the affordability measures are analysed to establish whether $Y$ is Granger caused by $X$ (i.e. the past values of $X$ can forecast the future values of $Y$ ). The Wald exogeneity test reveals that the affordability ratio (2 lags) shows evidence of 
causality to repayment affordability, however there is no reverse causality from repayment affordability to the House price-Income ratio, demonstrating a uni-directional relationship between the differing measures of affordability. The Pairwise Granger non-causality test (2 lags $)^{8}$ also confirms the uni-directional nature of the relationship between the two measures, showing the ratio measure to Granger cause repayment affordability.

\section{$<$ Table 11> Wald Exogeneity and Granger Causality testing}

\section{Impulse Response Functions}

Impulse response functions are further employed using the Cholesky decomposition test (dof adjusted) to examine the unit shocks within the VAR system and responsiveness of the dependent variable. The findings are consistent with the results emanating from the causality analysis and show that a one standard deviation shock in repayment affordability has a large and persistent, albeit diminishing positive influence on repayment affordability over the ten periods (Figure $2 a$ ). In contrast, a shock to the ratio affordability initially negatively influences a reaction in repayment affordability for two periods and shows a small positive but gradual effect after a three period lag. The residual decomposition method was also employed as it implicitly assumes no contemporaneous correlation amongst the residuals. The GIRF findings show a one standard deviation shock in the ratio measure has a sharp positive effect on the repayment measure and then becomes relatively steady after 4 lag periods (Figure $2 b$ ). A shock in repayment affordability upon the ratio affordability measure shows a soft but negative reaction which plateaus after four periods.

$<$ Figure 2(a),(b) $>$ Generalised Impulse Response Functions

\section{Conclusions}

Governments across most advanced economies are committed to ensuring that housing affordability remains within an acceptable level, as a priority to build inclusive societies and sustainable and functional communities. From a policy perspective, understanding affordability is central to achieving the socio-economic goals of government and tackling the social disparity and socio-economic segregation within society. The methodological approach undertaken in this paper represents an advancement in terms of conceptualising and quantifying housing affordability. Past affordability analysis has had the tendency to apply narrowly defined ratios or more subjective residual techniques, each of which claim to be the superlative approach. However, the findings stemming from this study illustrates that they require integration and are in fact complementary, analysis that provides empirical support for other work such as Haffner and Heylen (2011). Nonetheless, whilst the analysis of the concepts is complementary, as evidenced by no long-term cointegration, the results do

\footnotetext{
${ }^{8}$ The Granger causality and Wald tests were tested for further lag effects. All lags above 2 showed no statistical significance at the $95 \%$ level.
} 
suggest that there is statistically significant causal effect between the two access and repayment measures - illustrating that employing one measure can help analyse to other - if people are struggling to access now people will struggle to repay later.

The analysis also reveals that housing market affordability is contextualised by the interaction of a number of disparate indicators reflective of the wider financial and macroeconomic environment. This is significant for the contested nature of affordability and policy formulation across various policy settings. Indeed, the findings suggest that there are no easy assumptions with regards to the role and effect of market practices or government policy. There is evidence of feedback loops in aspects such as LTV for example, which initially act to positively address an aspect of affordability, but which subsequently exacerbate the situation either directly or indirectly via a change in another aspect. This suggests that policy makers need to look deeper at the causes of affordability problems and act in more subtle, nuanced ways.

The findings have shown that both the access and repayment approaches to affordability are of relevance to policymakers. The application of one particular measure over another can disguise truer reflections of long-term and short-term difficulties in the housing life-cycle. Effective policy requires a more holistic perspective, a broader definition and a more comprehensive set of policy interventions tuned to the market cycle and the support mechanisms required by various market participants.

\section{References}

Abelson, P. (2009) Affordable Housing: Concepts and Policies, Economic Papers, Vol. 28, No. 1, March, 2009, 27-38.

Bramley, G (1994) An affordability crisis in British housing: Dimensions, causes and policy impact, Housing Studies, Vol. 9, No. 1, pp. 103-124

Bramley, G and Karley, N (2005) How much extra affordable housing is needed in England?, Housing Studies, Vol. 20, pp. 685-715

Burke, T (2001) Measuring Housing Affordability, Swinburne Monash AHURI Centre, Swinburne University of Technology

Burke, T., Neske, C. and Ralston, L (2004) Housing Affordability, report for Department of Premier and Cabinet, Melbourne

Chaplin, R. \& Freeman, A (1999) Towards an Accurate Description of Affordability, Urban Studies, Vol. 36, No. 1, pp. 1949-1957

Coombes, M.G. and Wong, C. (1994) Methodological steps in the development of multivariate indexes for urban and regional policy analysis. Environment and Planning A, Vol. 26, pp. 1297-1316.

Freeman, A., Chaplin, R., Whitehead, C. M. E (1997) Rental Affordability: A Review of international literature, Cambridge Property Research Unit, University of Cambridge, Discussion Paper 88.

Gabriel, M., Jacobs, J., Arthurson, K., Burke, T \& Yates, J (2006) Conceptualising and measuring the housing affordability problem, Background Report, Melbourne, AHURI.

Gan, Q \& Hill, R. J (2009) Measuring Housing Affordability: Looking Beyond the Median, Journal of Housing Economics, Vol. 18, pp. 115-125 
Haffner, M. \& Heylen, K (2011) User Costs and Housing Expenses: Towards a more Comprehensive Approach to Affordability, Housing Studies, 26:04, 593-614

Hancock, K. E (1993) 'Can Pay? Won't Pay?' or Economic Principles of Affordability, Urban Studies, Vol. 30, No. 1, pp. 127-145

HNZC (2004) Building the Future: Towards a New Zealand Housing Strategy, Housing New Zealand Corporation, Wellington

Hulchanski, D. J (2005) Rethinking Canada's Housing Affordability Challenge: a discussion paper, Centre for Urban and Community Studies, University of Toronto, January

Jones, C., Watkins, C. \& Watkins, D (2011) Measuring local affordability: variations between housing market areas, International Journal of Housing Markets and Analysis, Vol.4, No. 4, pp. 341-356

Kaiser H. F (1974) An index of factorial simplicity, Psychometrika, Vol. 39, pp. 31-36

Katz, B., Turner, M., Brown, K., Cunningham, M. and Sawyer, N (2003) Rethinking Local Affordable Housing Strategies: Lessons from 70 Years of Policy and Practice, Brookings Institute Centre on Urban and Metropolitan Policy and Urban Institute, Washington

Kutty, N (2007) Housing Affordability in the United States: Price and Income Contributors http://ssrn.com/abstract=1002249

Linneman, P. D. \& Megbolugbe, I. F (1992) Housing Affordability: Myth or Reality?, Urban Studies, Vol. 29, No. 3, pp. 369-392

McCord, M., McGreal, S., Berry, J., Haran, M. \& Davis, P (2011) Implications of mortgage finance on housing market affordability, International Journal of Housing Markets and Analysis, Vol.4, No. 4, pp. 394-417

Mengie, L., Reed, R., and Wu, H. (2008) Challenges facing housing affordability in Beijing in the twenty-first century, International Journal of Housing Market and Analysis, Vol. 1, No. 3, pp. 275-287

Milligan, V. (2003) How Different? Comparing Housing Policies and Housing Affordability Consequences for Low Income Households in Australia and the Netherlands, Netherlands Geographical Studies, no. 318, University of Utrecht, Utrecht

Ndubueze, O. (2007) Measuring Housing Affordability: A Composite Approach, Paper Presented at the ENHR 2007 International Conference 'Sustainable Urban Areas', 25th-28th June

Pomerov, S (2004) Toward a comprehensive affordable housing strategy for Canada, in Hulchanski, D. J. and Shapcott, M (Eds) Finding Room: Policy Options for a Canadian Rental Housing Strategy, Centre for Urban and Community Studies, University of Toronto

Stevens, M (2002) Applied Multivariate statistics for the social sciences, $\left(4^{\text {th }}\right.$ Ed), Hillside, NJ: Erlbaum

Stone, M.E. (1993) Shelter Poverty: New Ideas on Housing Affordability, Philadelphia, PA, Temple University Press

Stone, M. E (2006) A Housing Affordability Standard for the UK, Housing Studies, Vol. 21, No. 4, pp. 453-476

Trimbath, S. \& Montoya, J (2002) Housing affordability in three dimensions: price, income and interest rates, Policy Brief, Number 31

Whitehead, C. M. E (1991) From need to affordability: an analysis of UK housing objectives, Urban Studies, Vol. 28, pp. 871-887

Whitehead, C. M. E (1999) Urban Housing Markets: Theory and Policy, Handbook of Regional and Urban Economics, Vol. 3, pp. 1559-1594

Wilcox, S. (1999). The vexed question of affordability (Vol. 7). Edinburgh: Scottish Homes.

Wilcox, S (2005) Local affordability issues for working households buying their first home, Joseph Rowntree Foundation 
1

2

3

4

5

6

7

8

9

10

11

12

13

14

15

16

17

18

19

20

21

22

23

24

25

26

27

28

29

30

31

32

33

34

35

36

37

38

39

40

41

42

43

44

45

46

47

48

49

50

51

52

53

54

55

56

57

58

59

60

Yang, Z and Chen, Y (2008) The affordability of owner occupied housing in Beijing, Journal of Housing and the Built Environment, Vol. 23, pp. 317-335 
Tables and Figures

$<$ Table 1 > Data sources and description

\begin{tabular}{lll}
\hline Variable & Source & Description \\
\hline $\begin{array}{l}\text { LQ House Price } \\
\text { User Cost }\end{array}$ & $\begin{array}{l}\text { UUHPI } \\
\text { Authors } \\
\text { calculations } \\
\text { BoE }\end{array}$ & $\begin{array}{l}\text { Lower quartile average house price } \\
\text { user cost formula proposed by Poterba (1992) } \\
\text { MIR }\end{array}$ \\
$\begin{array}{l}\text { Weighted average interest rates, premised on three year fixed } \\
\text { mortgage }(90 \% \mathrm{LTV})\end{array}$ \\
$\begin{array}{l}\text { Leposit } \\
\text { Lower quartile income }\end{array}$ \\
$\begin{array}{l}\text { Mort. finance } \\
\text { Borrow cost }\end{array}$ & $\mathrm{CML}$ & $\begin{array}{l}\text { Percentage required to be remunerated to obtain the } \\
\text { remaining outstanding amount required to purchase housing } \\
\text { services } \\
\text { Number of new FTB loans advanced } \\
\text { The interest payment as a percentage of income }\end{array}$ \\
\hline
\end{tabular}

$<$ Table 2> Summary of PCA results

\begin{tabular}{lcc}
\hline & COMPONENT 1 & COMPONENT 2 \\
\hline Borrow cost & .946 & .737 \\
Deposit & .909 & \\
LQ House Price & .884 & -.422 \\
LQ Income & .844 & -.484 \\
Mort. Finance & -.824 & \\
LTV & .813 & \\
User Cost & .766 & .516 \\
MIR & & .927 \\
Eigenvalues & 4.711 & 1.690 \\
\% of variance & 67.299 & 21.571 \\
\hline
\end{tabular}

<Table 3> Augmented Dickey-Fuller Unit Root Tests

\begin{tabular}{lcc}
\hline & $\boldsymbol{t}$-levels & $\boldsymbol{t} \mathbf{- 1}^{\text {ST }}$ Diff. \\
\hline BORROW COST & -2.6732 & $-6.644950^{*}$ \\
DEPOSIT & -2.1939 & $-2.193882^{*}$ \\
LQ HP & -3.3612 & $-5.225427 *$ \\
INCOME & -2.0723 & $-11.79183^{*}$ \\
LTV & -3.0885 & $-7.466654^{*}$ \\
MORT FINANCE & -1.4352 & $-9.542106^{*}$ \\
SVR MIR & -3.2523 & $-4.580804^{*}$ \\
USER COST & $-2.831488^{*}$ & - \\
\hline *MacKinnon (1996) one-sided p-values, Lag Length: 1 (Automatic - based on SIC, maxlag=10)
\end{tabular}

$<$ Table 4> Cointegration Results between the Affordability Indicators 


\begin{tabular}{ccccc}
\hline \multicolumn{6}{c}{ Unrestricted Cointegration Rank Test (Trace) } & Trace & 0.05 & \\
\hline Hypothesized & & Critical Value & Prob. $^{* *}$ \\
No. of CE(s) & Eigenvalue & Statistic & C. & \\
None & 0.130164 & 9.222073 & 15.49471 & 0.3453 \\
At most 1 & 0.006907 & 0.436658 & 3.841466 & 0.5087 \\
\hline None * & 0.966360 & 508.7299 & 159.5297 & 0.0000 \\
At most 1 * & 0.802718 & 301.8154 & 125.6154 & 0.0000 \\
At most 2 * & 0.666780 & 202.8049 & 95.75366 & 0.0000 \\
At most 3 * & 0.584320 & 135.7689 & 69.81889 & 0.0000 \\
At most 4 * & 0.438924 & 82.22062 & 47.85613 & 0.0000 \\
At most 5 * & 0.359659 & 46.96883 & 29.79707 & 0.0002 \\
At most 6 * & 0.171129 & 19.77778 & 15.49471 & 0.0106 \\
\hline
\end{tabular}

Unrestricted Cointegration Rank Test (Maximum Eigenvalue)

Hypothesized Max-Eigen 0.05

No. of CE(s)

Eigenvalue

Statistic

Critical Value

Prob.**

None *

0.966360

206.9145

52.36261

0.0001

At most 1 *

0.802718

99.01050

46.23142

0.0000

At most 2 *

0.666780

67.03601

40.07757

0.0000

At most 3 *

0.584320

53.54828

33.87687

0.0001

At most 4 *

0.438924

35.25179

27.58434

0.0043

At most 5 *

0.359659

27.19105

21.13162

0.0062

At most 6

0.171129

11.44916

14.26460

0.1331

Trace test indicates 7 cointegrating eqn(s) at the 0.05 level; Max-eigenvalue test indicates 6 cointegrating eqn $(\mathrm{s})$ at the 0.05 level;* denotes rejection of the hypothesis at the 0.05 level;**MacKinnon-Haug-Michelis (1999) pvalues.

< Table 5> Long-term Causality between variables

\begin{tabular}{lcccccc}
\hline \multicolumn{1}{c}{ DV } & Coefficient & $\begin{array}{c}\text { Std. } \\
\text { Error }\end{array}$ & $t$-Stat. & $R^{2}$ & Adj. $R^{2}$ & $F$ \\
\hline LQ HOUSE PRICE & 0.144207 & 0.075527 & 1.909339 & 0.9992 & 0.9964 & $355.05^{*}$ \\
BORROWCOST & $5.14 \mathrm{E}-05$ & 0.000112 & 0.458403 & 0.9463 & 0.7523 & $4.871^{*}$ \\
DEPOSIT & 1.100985 & 0.327692 & $3.359816^{*}$ & 0.9638 & 0.8331 & $7.375^{*}$ \\
LQ INCOME & 0.280339 & 0.129638 & $2.162471^{* *}$ & 0.9261 & 0.6591 & $3.469^{*}$ \\
LTV & $-8.03 \mathrm{E}-06$ & $2.52 \mathrm{E}-06$ & $-3.191355^{*}$ & 0.9436 & 0.7401 & $4.634^{*}$ \\
MORT FINANCE & 0.138501 & 0.055125 & $2.512472^{* *}$ & 0.9691 & 0.8577 & $8.695^{*}$ \\
MIR & $-1.17 \mathrm{E}-07$ & $3.43 \mathrm{E}-07$ & -0.340586 & 0.9210 & 0.6397 & $3.228^{*}$ \\
USERCOST & -0.041362 & 0.590392 & -0.070059 & 0.9321 & 0.6867 & $3.799^{*}$ \\
\hline
\end{tabular}

*significant at the $99 \%$; **significant at the $95 \%$ level.

<Table 6> Wald Exogeneity Test

\begin{tabular}{l|lll}
\hline & $F$-stat. & $\chi^{2}$ & S-T Causality \\
\hline LQ HOUSE PRICE $\rightarrow$ LQ HOUSE PRICE & 1.3492 & 6.746 & $\mathbf{x}$ \\
BORROWCOST $\rightarrow$ LQ HOUSE PRICE & 0.7767 & 3.883 & $\mathbf{x}$ \\
DEPOSIT $\rightarrow$ LQ HOUSE PRICE & 1.189 & 5.945 & $\mathbf{x}$ \\
LQ INCOME $\rightarrow$ LQ HOUSE PRICE & 1.7785 & 8.829 & $\mathbf{x}$
\end{tabular}


LTV $\rightarrow$ LQ HOUSE PRICE MORT FINANCE $\rightarrow$ LQ HOUSE PRICE MIR $\rightarrow$ LQ HOUSE PRICE USERCOST $\rightarrow$ LQ HOUSE PRICE

\begin{tabular}{l}
\hline LQ HOUSE PRICE $\rightarrow$ BORROWCOST \\
\hline BORROWCOST $\rightarrow$ BORROWCOST
\end{tabular}

BORROWCOST $\rightarrow$ BORROWCOST

DEPOSIT $\rightarrow$ BORROWCOST

LQ INCOME $\rightarrow$ BORROWCOST

LTV $\rightarrow$ BORROWCOST

MORT FINANCE $\rightarrow$ BORROWCOST

MIR $\rightarrow$ BORROWCOST

USERCOST $\rightarrow$ BORROWCOST

\begin{tabular}{l}
\hline LQ HOUSE PRICE $\rightarrow$ DEPOSIT \\
\hline
\end{tabular}

BORROWCOST $\rightarrow$ DEPOSIT

DEPOSIT $\rightarrow$ DEPOSIT

LQ INCOME $\rightarrow$ DEPOSIT

LTV $\rightarrow$ DEPOSIT

MORT FINANCE $\square$ DEPOSIT

MIR $\rightarrow$ DEPOSIT

USERCOST $\rightarrow$ DEPOSIT

\begin{tabular}{ll}
\hline \\
\hline LQ HOUSE PRICE $\rightarrow$ LQ INCOME
\end{tabular}

LQ HOUSE PRICE $\rightarrow$ LQ INCOME

BORROWCOST $\rightarrow$ LQ INCOME

DEPOSIT $\rightarrow$ LQ INCOME

LQ INCOME $\rightarrow$ LQ INCOME

LTV $\rightarrow$ LQ INCOME

MORT FINANCE $\rightarrow$ LQ INCOME

MIR $\rightarrow$ LQ INCOME

USERCOST $\rightarrow$ LQ INCOME

\begin{tabular}{l|lll}
\hline & $F$-stat. & $\chi 2$ & S-T Causality \\
\hline LQ HOUSE PRICE $\rightarrow$ LTV & $4.8265^{*}$ & $24.132^{*}$ & $\checkmark$ \\
BORROWCOST $\rightarrow$ LTV & 0.8296 & 4.148 & $\mathbf{x}$ \\
DEPOSIT $\rightarrow$ LTV & 1.1075 & 5.537 & $\mathbf{x}$ \\
LQ INCOME $\rightarrow$ LTV & $2.1898^{* * *}$ & $10.949^{* * *}$ & $\checkmark$ \\
LTV $\rightarrow$ LTV & 1.9626 & $9.813^{* * *}$ & $\checkmark$ \\
MORT FINANCE $\rightarrow$ LTV & 1.2356 & 6.178 & $\mathbf{x}$ \\
MIR $\rightarrow$ LTV & $3.4096^{* *}$ & $17.048^{*}$ & $\checkmark$ \\
USERCOST $\rightarrow$ LTV & $4.8941^{*}$ & $24.470^{*}$ & $\checkmark$ \\
\hline & $F$-stat. & $\chi 2$ & S-T Causality \\
\hline LQ HOUSE PRICE $\rightarrow$ MORT FINANCE & 1.6219 & 8.109 & $\mathbf{x}$ \\
BORROWCOST $\rightarrow$ MORT FINANCE & $4.9466^{*}$ & $24.733^{*}$ & $\checkmark$ \\
DEPOSIT $\rightarrow$ MORT FINANCE & 1.4407 & 7.203 & $\mathbf{x}$ \\
LQ INCOME $\rightarrow$ MORT FINANCE & $3.0123^{* *}$ & $15.061^{* *}$ & $\checkmark$
\end{tabular}




\begin{tabular}{l|lll} 
LTV $\rightarrow$ MORT FINANCE & 1.9437 & $9.718^{* * *}$ & $\checkmark$ \\
MORT FINANCE $\rightarrow$ MORT FINANCE & $18.308^{*}$ & $91.541^{*}$ & $\checkmark$ \\
MIR $\rightarrow$ MORT FINANCE & $4.5255^{* *}$ & $22.627^{*}$ & $\checkmark$ \\
USERCOST $\rightarrow$ MORT FINANCE & 1.672 & 8.36 & $\mathbf{x}$ \\
\hline & $F$-stat. & $\chi 2$ & S-T Causality \\
\hline LQ HOUSE PRICE $\square$ MIR & 0.3174 & 1.587 & $\mathbf{x}$ \\
BORROWCOST $\square$ MIR & 1.8438 & 9.219 & $\mathbf{x}$ \\
DEPOSIT $\square$ MIR & 1.5184 & 7.592 & $\mathbf{x}$ \\
LQ INCOME $\square$ MIR & $2.2896^{* * *}$ & $11.448^{* *}$ & $\checkmark$ \\
LTV $\square$ MIR & 2.2229 & $11.114^{*}$ & $\checkmark$ \\
MORT FINANCE $\square$ MIR & 1.0475 & 5.237 & $\mathbf{x}$ \\
MIR $\square$ MIR & 2.0712 & $10.356^{* *}$ & $\checkmark$ \\
USERCOST $\square$ MIR & 0.5234 & 2.617 & $\mathbf{x}$ \\
\hline & $F$-stat. & $\chi 2$ & S-T Causality \\
\hline LQ HOUSE PRICE $\square$ USERCOST & 1.5868 & 7.934 & $\mathbf{x}$ \\
BORROWCOST $\square$ USERCOST & 0.5307 & 2.653 & $\mathbf{x}$ \\
DEPOSIT $\square$ USERCOST & $2.8094 * * *$ & $14.047^{* *}$ & $\checkmark$ \\
LQ INCOME $\square$ USERCOST & 0.5404 & 2.702 & $\mathbf{x}$ \\
LTV $\square$ USERCOST & 1.1645 & 5.822 & $\mathbf{x}$ \\
MORT FINANCE $\square$ USERCOST & 0.5542 & 2.771 & $\mathbf{x}$ \\
MIR $\square$ USERCOST & 0.6902 & 3.451 & $\mathbf{x}$ \\
USERCOST $\square$ USERCOST & 1.4874 & 7.437 & $\mathbf{x}$ \\
\hline
\end{tabular}

$\rightarrow$ denotes "does not Granger cause"; *significant at the $99 \%$ level; **95\% level; ***90\% level.

$<$ Table 7> Granger Causality over various lag periods

\begin{tabular}{lccccc}
\hline Granger causality Test & \multicolumn{5}{c}{ No. of Lags } \\
\hline & 2 & 3 & 4 & 5 & 6 \\
& & & F-stat. \\
\hline $\mathrm{HP} \rightarrow \mathrm{BC}$ & $13.8671^{*}$ & $8.96722^{*}$ & $6.61350^{*}$ & $5.32250^{*}$ & $4.53655^{*}$ \\
$\mathrm{BC} \rightarrow \mathrm{HP}$ & 1.0971 & 0.52056 & 0.60287 & 0.47641 & 0.45640 \\
$\mathrm{D} \rightarrow \mathrm{BC}$ & $6.99493^{*}$ & $7.62552^{*}$ & $5.40413^{*}$ & $4.24002^{*}$ & $3.36964^{*}$ \\
$\mathrm{BC} \rightarrow \mathrm{D}$ & $3.11916^{* * *}$ & $2.49309^{* *}$ & 1.68345 & 1.46797 & 1.37312 \\
$\mathrm{IN} \rightarrow \mathrm{BC}$ & $6.77129^{*}$ & $4.32451^{*}$ & $3.25015^{* *}$ & $2.78007^{* *}$ & $2.51845^{* *}$ \\
$\mathrm{BC} \rightarrow \mathrm{IN}$ & 1.78952 & 1.87233 & 1.38234 & 1.64558 & 1.14236 \\
$\mathrm{LTV} \rightarrow \mathrm{BC}$ & $4.34357^{* *}$ & $5.00006^{*}$ & $3.97556^{*}$ & $3.41246^{*}$ & $2.99289^{* *}$ \\
$\mathrm{BC} \rightarrow \mathrm{LTV}$ & $6.34555^{*}$ & $3.73566^{* *}$ & $2.20021^{* * *}$ & 1.85987 & 1.71992 \\
$\mathrm{MF} \rightarrow \mathrm{BC}$ & 2.34125 & $2.77729^{* *}$ & $3.45026^{*}$ & $2.75886^{* *}$ & $2.68537^{* *}$ \\
$\mathrm{BC} \rightarrow \mathrm{MF}$ & 1.76066 & 1.15301 & 1.16733 & 1.60537 & 1.07298 \\
$\mathrm{MIR} \rightarrow \mathrm{BC}$ & $4.58585^{* *}$ & $3.07010^{* *}$ & $3.55443^{* *}$ & $3.03807^{* *}$ & $2.66077^{* *}$ \\
$\mathrm{BC} \rightarrow \mathrm{MIR}$ & $3.20253^{* *}$ & 2.01450 & 1.95169 & 1.14975 & 1.38820 \\
$\mathrm{UC} \rightarrow \mathrm{BC}$ & $5.31742^{*}$ & $3.63116^{* *}$ & $2.61652^{* *}$ & $2.50592^{* *}$ & $2.55625^{* *}$ \\
$\mathrm{BC} \rightarrow \mathrm{UC}$ & $4.51432^{* *}$ & $3.05440^{* *}$ & $2.28648^{* * *}$ & $2.10795^{* * *}$ & 1.64579 \\
\hline & & & & &
\end{tabular}




\begin{tabular}{|c|c|c|c|c|c|}
\hline $\mathrm{D} \rightarrow \mathrm{HP}$ & $11.3642^{*}$ & $17.2048^{*}$ & $13.7073^{*}$ & $11.9169^{*}$ & $6.26068^{*}$ \\
\hline $\mathrm{HP} \rightarrow \mathrm{D}$ & $10.3505^{*}$ & $8.27717^{*}$ & $7.20023^{*}$ & $10.4407^{*}$ & $14.2914^{*}$ \\
\hline $\mathrm{IN} \rightarrow \mathrm{HP}$ & $3.76407^{* *}$ & 1.93996 & 1.95213 & 1.47609 & 0.77061 \\
\hline $\mathrm{HP} \rightarrow \mathrm{IN}$ & $13.7849 *$ & 9.95581* & $7.40095^{*}$ & $7.60523^{*}$ & $5.72631^{*}$ \\
\hline $\mathrm{LTV} \rightarrow \mathrm{HP}$ & $5.27964 *$ & $6.97578^{*}$ & $5.21074^{*}$ & $4.36185^{*}$ & $3.02854^{* *}$ \\
\hline $\mathrm{HP} \rightarrow \mathrm{LTV}$ & $10.7671^{*}$ & $6.33863^{*}$ & $3.95847^{*}$ & $3.61024 *$ & $9.58072^{*}$ \\
\hline $\mathrm{MF} \rightarrow \mathrm{HP}$ & 0.10193 & 0.64679 & 0.52068 & 0.47031 & 0.66712 \\
\hline $\mathrm{HP} \rightarrow \mathrm{MF}$ & $4.54878^{* *}$ & $3.10798^{* *}$ & $3.64178^{* *}$ & $2.51094^{* *}$ & 1.73812 \\
\hline $\mathrm{MIR} \rightarrow \mathrm{HP}$ & 2.39027 & 1.96953 & 1.31720 & 1.04506 & 1.16695 \\
\hline $\mathrm{HP} \rightarrow \mathrm{MIR}$ & $8.01983 *$ & $6.03948^{*}$ & 4.19993* & $3.78136^{*}$ & 4.15198* \\
\hline $\mathrm{UC} \rightarrow \mathrm{HP}$ & $1627.31^{*}$ & $1008.73 *$ & 794.359* & $1052.42^{*}$ & $736.270^{*}$ \\
\hline $\mathrm{HP} \rightarrow \mathrm{UC}$ & $6.82471^{*}$ & $6.38518^{*}$ & $5.48151^{*}$ & $4.15778^{*}$ & $3.04518^{* *}$ \\
\hline $\mathrm{IN} \rightarrow \mathrm{D}$ & $5.79319 *$ & $4.57038^{*}$ & $4.42001^{*}$ & $3.81050^{*}$ & $3.19355^{*}$ \\
\hline $\mathrm{D} \rightarrow \mathrm{IN}$ & 1.30125 & $2.66309 * * *$ & $2.54983 * *$ & $2.58039^{* *}$ & 1.48858 \\
\hline $\mathrm{LTV} \rightarrow \mathrm{D}$ & 0.72630 & 1.02651 & 1.41479 & 1.88788 & 3.16324 \\
\hline $\mathrm{D} \rightarrow \mathrm{LTV}$ & 1.45862 & 1.08509 & 0.92697 & 0.95174 & 2.80400 \\
\hline $\mathrm{MF} \rightarrow \mathrm{D}$ & 1.04403 & 0.74861 & 0.63826 & 0.48180 & 0.33836 \\
\hline $\mathrm{D} \rightarrow \mathrm{MF}$ & 3.44455 & 1.99897 & 1.85220 & 1.42576 & 1.01473 \\
\hline $\mathrm{MIR} \rightarrow \mathrm{D}$ & 0.56118 & 0.92244 & 0.64342 & 0.59768 & 0.63096 \\
\hline $\mathrm{D} \rightarrow \mathrm{MIR}$ & $4.11600 * *$ & $3.96636 * *$ & $2.86156^{* *}$ & $2.08456 * * *$ & 1.79233 \\
\hline$U C \rightarrow D$ & $7.52842^{*}$ & $8.45282^{*}$ & $8.06544 *$ & 11.5771* & $18.5504^{*}$ \\
\hline$D \rightarrow U C$ & $15.1328 *$ & $14.5808^{*}$ & $12.0102^{*}$ & $8.83548^{*}$ & $6.48235^{*}$ \\
\hline LTV $\rightarrow$ IN & 0.63281 & 1.70137 & 1.58469 & 1.53035 & 0.86025 \\
\hline IN $\rightarrow$ LTV & 9.12239* & $5.54949 *$ & $3.65441^{* *}$ & $3.12939 * *$ & $2.47663^{* *}$ \\
\hline $\mathrm{MF} \rightarrow \mathrm{IN}$ & 0.17438 & 0.60068 & 0.64427 & 0.60253 & 0.80873 \\
\hline $\mathrm{IN} \rightarrow \mathrm{MF}$ & $3.87351^{* *}$ & $3.36380^{* *}$ & $3.74202^{*}$ & $2.81445^{* *}$ & $2.15748^{* * *}$ \\
\hline $\mathrm{MIR} \rightarrow \mathrm{IN}$ & 1.82992 & 1.26282 & 1.42316 & 0.82910 & 0.79801 \\
\hline $\mathrm{IN} \rightarrow \mathrm{MIR}$ & 1.92835 & 1.14160 & 1.46965 & 0.77375 & 0.81676 \\
\hline$U C \rightarrow I N$ & $10.8320^{*}$ & $8.23013^{*}$ & $6.47188^{*}$ & $6.01014^{*}$ & 4.50681* \\
\hline$I N \rightarrow U C$ & $3.30842^{* *}$ & 1.84837 & 1.46120 & 1.47526 & 1.68821 \\
\hline $\mathrm{MF} \rightarrow \mathrm{LTV}$ & 1.92197 & 0.78697 & 0.67018 & 0.57842 & 0.45576 \\
\hline $\mathrm{LTV} \rightarrow \mathrm{MF}$ & 1.76303 & 0.94079 & 0.64120 & 0.49973 & 0.34681 \\
\hline $\mathrm{MIR} \rightarrow \mathrm{LTV}$ & 0.24487 & 0.83173 & 0.33883 & 0.30977 & 0.64692 \\
\hline $\mathrm{LTV} \rightarrow \mathrm{MIR}$ & $2.46250^{* * *}$ & $2.25134^{* * *}$ & $2.52873^{* * *}$ & 1.90573 & 1.57438 \\
\hline $\mathrm{UC} \rightarrow \mathrm{LTV}$ & 1.23910 & $2.20149 * * *$ & $2.39651^{* * *}$ & $2.71364^{* *}$ & 9.18951* \\
\hline $\mathrm{LTV} \rightarrow \mathrm{UC}$ & $11.8413^{*}$ & $8.87140 *$ & $7.18485^{*}$ & $6.48139 *$ & $5.30389 *$ \\
\hline $\mathrm{MIR} \rightarrow \mathrm{MF}$ & 1.63224 & $2.67111^{* * *}$ & $5.50793 *$ & $4.16048^{*}$ & $3.71224^{*}$ \\
\hline $\mathrm{MF} \rightarrow \mathrm{MIR}$ & 0.63337 & 0.38023 & 1.09712 & 0.90321 & 0.86085 \\
\hline $\mathrm{UC} \rightarrow \mathrm{MF}$ & 1.20731 & 0.80377 & 1.86654 & 1.45772 & 0.90588 \\
\hline $\mathrm{MF} \rightarrow \mathrm{UC}$ & $3.52473^{* *}$ & 1.82425 & 1.38126 & 1.51151 & 1.06421 \\
\hline $\mathrm{UC} \rightarrow \mathrm{MIR}$ & $7.92402 *$ & $5.37162^{*}$ & $3.80656^{*}$ & $3.46984^{*}$ & $3.93157^{*}$ \\
\hline $\mathrm{MIR} \rightarrow \mathrm{UC}$ & 0.03622 & 0.42113 & 0.32152 & 1.66722 & 1.10281 \\
\hline
\end{tabular}

$\rightarrow$ denotes "does not Granger cause"; *significant at the $99 \%$ level; **95\% level; ***90\% level. 
<Table 8> Co-integration Testing of Affordability metrics

\begin{tabular}{ccccc}
\hline \multicolumn{5}{l}{ Unrestricted Cointegration Rank Test (Trace) } \\
\hline Hypothesized & Trace & 0.05 \\
No. of CE(s) & Eigenvalue & Statistic & Critical Value & Prob.** \\
None & 0.130164 & 9.222073 & 15.49471 & 0.3453 \\
At most 1 & 0.006907 & 0.436658 & 3.841466 & 0.5087 \\
\hline Unrestricted Cointegration Rank Test (Maximum Eigenvalue) \\
\hline Hypothesized & Max-Eigen & 0.05 \\
No. of CE(s) & Eigenvalue & Statistic & Critical Value & Prob.** \\
None & 0.130164 & 8.785414 & 14.2646 & 0.3045 \\
At most 1 & 0.006907 & 0.436658 & 3.841466 & 0.5087 \\
\hline
\end{tabular}

Trace test indicates no cointegrating eqn(s) at the 0.05 level; Max-eigenvalue test indicates no cointegrating eqn(s) at the 0.05 level;* denotes rejection of the hypothesis at the 0.05 level;**MacKinnon-Haug-Michelis (1999) pvalues.

<Table 9> VAR Models

\begin{tabular}{|c|c|c|c|c|}
\hline & \multicolumn{2}{|c|}{ VAR(1) } & \multicolumn{2}{|c|}{ VAR(2) } \\
\hline & REPAY & $\overline{\text { RATIO }}$ & REPAY & RATIO \\
\hline \multirow[t]{3}{*}{ REPAY(-1) } & 0.600087 & -0.1588 & 0.859791 & -0.13031 \\
\hline & $(0.14463)$ & $(0.08193)$ & $(0.25694)$ & $(0.13654)$ \\
\hline & [ 4.14908] & {$[-1.93810]$} & [ 3.34629] & {$[-0.95436]$} \\
\hline \multirow[t]{3}{*}{ RATIO(-1) } & 0.250490 & 1.047272 & -0.28313 & -0.01381 \\
\hline & $(0.16375)$ & $(0.09277)$ & $(0.26707)$ & $(0.14192)$ \\
\hline & [ 1.52969$]$ & [ 11.2893] & {$[-1.06013]$} & {$[-0.09732]$} \\
\hline \multirow[t]{3}{*}{ REPAY(-2) } & & & -0.60004 & 0.707561 \\
\hline & & & $(0.45460)$ & $(0.24158)$ \\
\hline & & & [-1.31993] & [ 2.92889] \\
\hline \multirow[t]{3}{*}{ RATIO(-2) } & & & 0.933544 & 0.379038 \\
\hline & & & $(0.45697)$ & $(0.24284)$ \\
\hline & & & [ 2.04290] & [ 1.56087$]$ \\
\hline \multirow[t]{3}{*}{ C } & 0.261185 & 0.129356 & 0.233230 & 0.090567 \\
\hline & $(0.08207)$ & $(0.04649)$ & $(0.08391)$ & $(0.04459)$ \\
\hline & [ 3.18258] & [ 2.78234] & [ 2.77945] & [ 2.03103] \\
\hline
\end{tabular}




\begin{tabular}{ccccc}
\hline R-squared & 0.657881 & 0.854408 & 0.708808 & 0.888911 \\
Adj. R-squared & 0.647190 & 0.849859 & 0.689713 & 0.881626 \\
Sum sq. resids & 0.546684 & 0.175448 & 0.464487 & 0.131169 \\
S.E. equation & 0.092423 & 0.052358 & 0.087261 & 0.046371 \\
F-statistic & 61.53473 & 187.7928 & 37.12088 & 122.0270 \\
Log likelihood & 66.01842 & 104.0921 & 69.91378 & 111.6405 \\
Akaike AIC & -1.8811 & -3.0177 & -1.96708 & -3.23153 \\
Schwarz SC & -1.7824 & -2.919 & -1.8012 & -3.06565 \\
Mean dependent & 1.029410 & 0.585224 & 1.028612 & 0.582879 \\
\hline
\end{tabular}

$<$ Table 10> VAR Residual Serial Correlation LM Tests and Lag Order Selection

\begin{tabular}{|c|c|c|c|c|c|c|c|c|}
\hline Lag & $\log L$ & LR & FPE & $\overline{A I C}$ & $\overline{S C}$ & HQ & LM-Stat & Prob \\
\hline $\mathbf{0}$ & 112.539 & NA & 0.000114 & -3.4012 & -3.3343 & -3.3748 & - & - \\
\hline 1 & 218.201 & 201.571 & $5.01 \mathrm{e}-06$ & -6.529 & $-6.328563 *$ & -6.450 & 13.13660 & 0.0106 \\
\hline 2 & 226.452 & $15.232 *$ & $4.39 \mathrm{e}-06^{*}$ & $-6.6600 *$ & -6.326 & $-6.528084 *$ & 2.546977 & 0.6362 \\
\hline 3 & 228.123 & 2.982 & $4.73 \mathrm{e}-06$ & -6.588 & -6.120 & -6.404 & 1.065656 & 0.8997 \\
\hline at & infor & $\begin{array}{l}\text { df; }{ }^{*} \\
\text { predi } \\
\text { iterio }\end{array}$ & 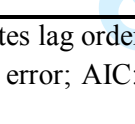 & & & & $\overline{\mathrm{d} \mathrm{I}}$ & . \\
\hline
\end{tabular}

Table 11 Wald Exogeneity and Granger Causality testing

\begin{tabular}{lcccccc}
\hline & & \multicolumn{2}{c}{ Granger Test } & \multicolumn{2}{c}{ Wald test } & \multicolumn{2}{c}{ Decision } \\
Direction of Causality & No. of Lags & $F$-stat. & $p$ & $\chi^{2}$ & $p$ & Reject \\
\hline Ratio $\rightarrow$ Repay & 2 & 3.4085 & 0.0395 & 6.8170 & 0.0331 & Do not reject \\
Repay $\rightarrow$ Ratio & 2 & 1.7947 & 0.1748 & 3.5894 & 0.1662 & .
\end{tabular}

$<$ Figure 1 $>$ Affordability metrics 


\section{$<$ Figure 2> Generalised Impulse Response Functions}

(a)

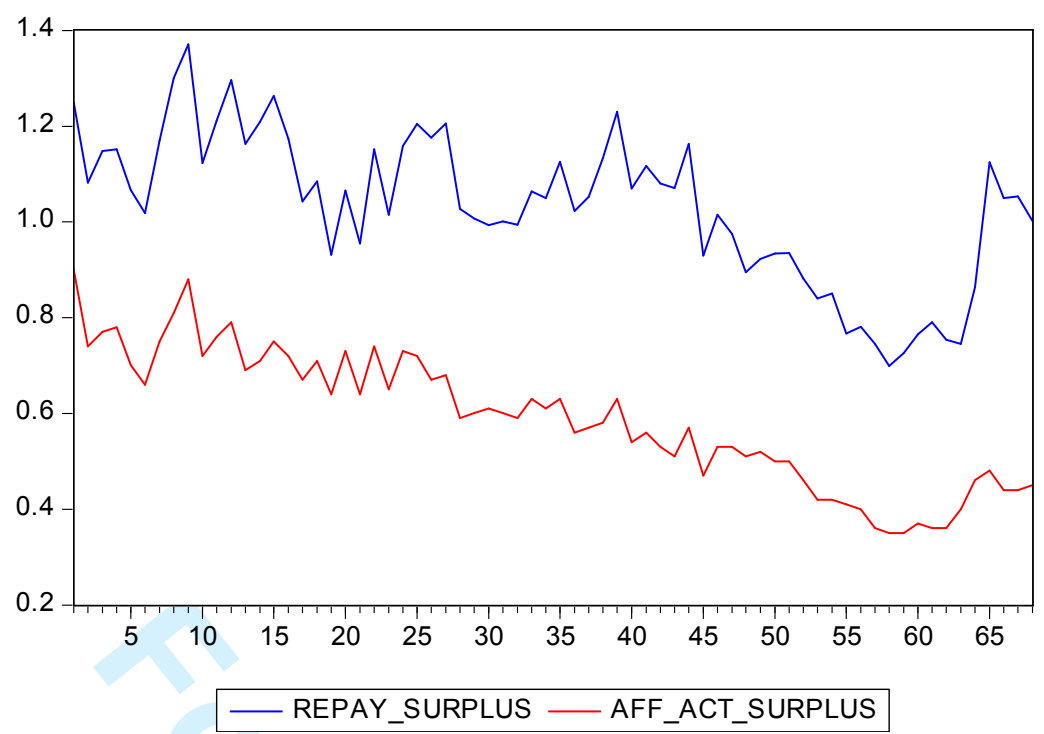

Response to Cholesky One S.D. Innovations \pm 2 S.E.



Response of REPAY SURPLUS to AFF_ACT_SURPLUS

Response of AFF_ACT_SURPLUS to REPAY_SURPLUS
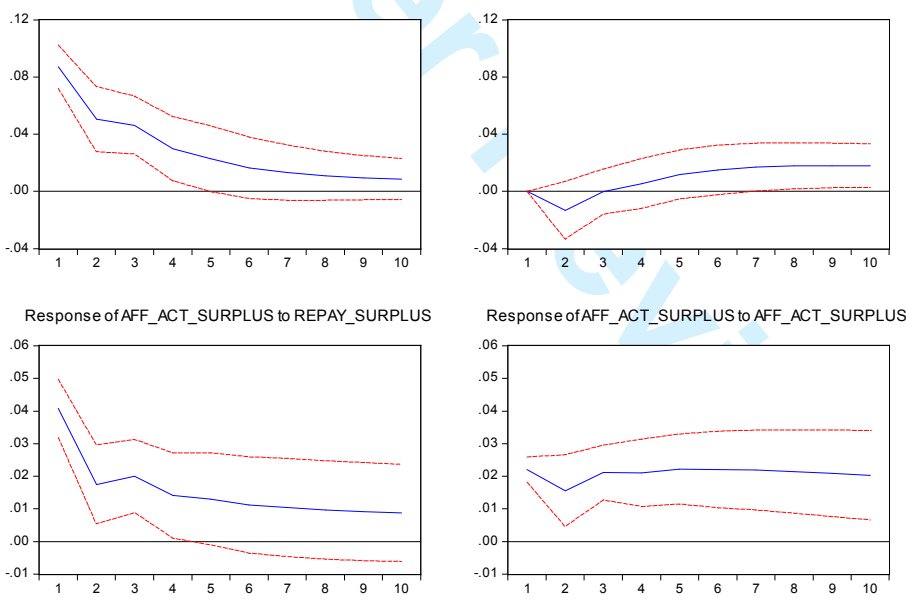
(b)

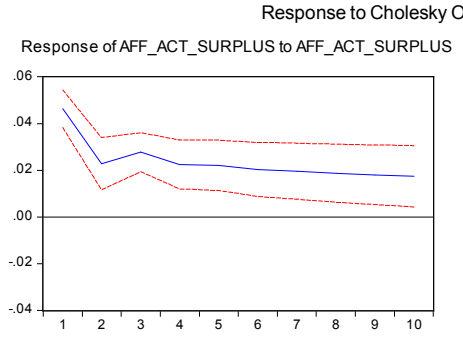

D. Innovations \pm 2 S.E.

Response of AFF_ACT_SURPLUS to REPAY_SURPLUS

Response of REPAY_SURPLUS to AFF_ACT_SURPLUS
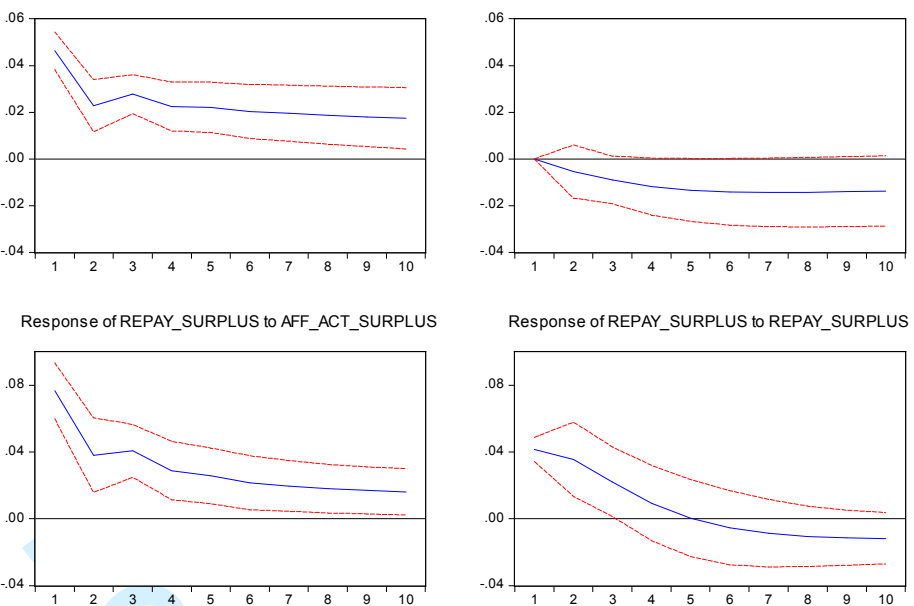

Response of REPAY_SURPLUS to REPAY_SURPLUS

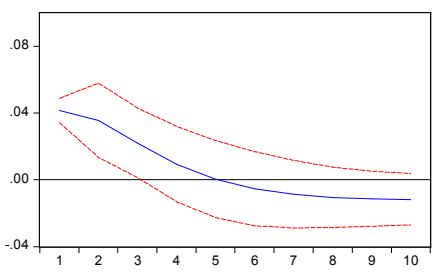

Response to Nonfactorized One S.D. Innovations \pm 2 S.E.

Response of REPAY_SURPLUS to REPAY_SURPLUS

Response of REPAY_SURPLUS to AFF_ACT_SURPLUS
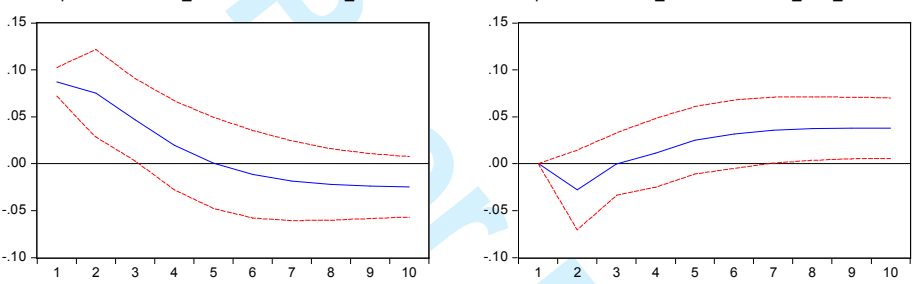

Response of AFF_ACT_SURPLUS to REPAY_SURPLUS

Response of AFF_ACT_SURPLUS to AFF_ACT_SURPLUS
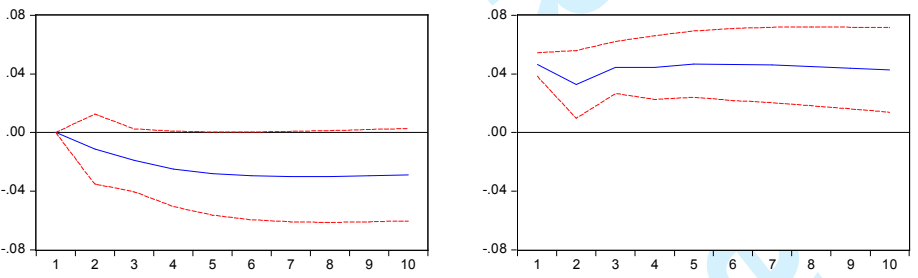


\section{Appendices}
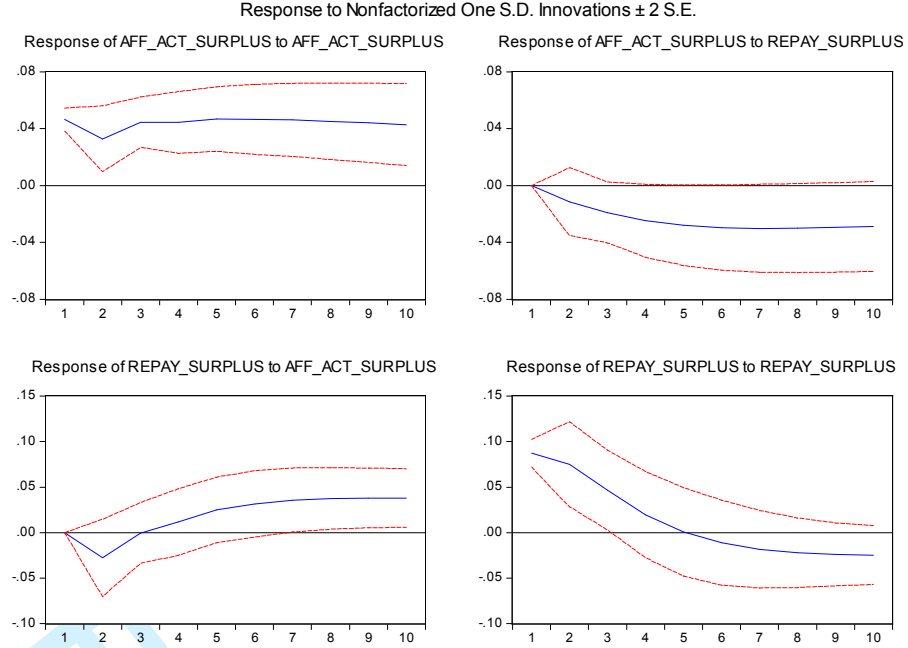

AR Roots Table for Model Stability

\begin{tabular}{cc}
\hline \hline Root & Modulus \\
\hline \hline 0.967580 & 0.967580 \\
0.518511 & 0.518511 \\
0.476356 & 0.476356 \\
-0.395094 & 0.395094 \\
\hline \multicolumn{2}{l}{ VAR satisfies the stability condition. } \\
No root lies outside the unit circle.
\end{tabular}

\section{Portmanteau autocorrelation tests shows no residual autocorrelation}

\begin{tabular}{llllll} 
Lags & Q-Stat & Prob. & Adj Q-Stat & Prob. & df \\
\hline \hline 1 & 0.655590 & NA* & 0.665676 & NA* & NA* \\
2 & 2.733523 & NA* $^{*}$ & 2.808544 & NA* & NA* $^{*}$ \\
3 & 3.416279 & 0.4907 & 3.523812 & 0.4743 & 4 \\
\hline \hline
\end{tabular}

*The test is valid only for lags larger than the VAR lag order. $\mathrm{df}$ is degrees of freedom for (approximate) chi-square distribution

\section{Variable trends}


DEPOSIT


\section{Appendix X Model Diagnostics}


1

2

3

4

5

6

7

8

9

10

11

12

13

14

15

16

17

18

19

20

21

22

23

24

25

26

27

28

29

30

31

32

33

34

35

36

37

38

39

40

41

42

43

44

45

46

47

48

49

50

51

52

53

54

55

56

57

58

59

60

\begin{tabular}{lcccc}
\hline & $\mathrm{F}$ & $\mathrm{p}$ & & $\mathrm{p}$ \\
LQ HOUSE PRICE & 0.7093 & 0.5924 & 1.886 & 0.3893 \\
BORROWCOST & 0.7763 & 0.5493 & 2.47 & 0.2907 \\
DEPOSIT & 1.9122 & 0.2575 & 1.551 & 0.4604 \\
LQ INCOME & 1.0565 & 0.4199 & 4.67 & 0.0968 \\
LTV & 2.635 & 0.2073 & 0.7545 & 0.6857 \\
MORT FINANCE & 0.9415 & 0.4647 & 0.7337 & 0.6929 \\
MIR & 1.378 & 0.3336 & 1.727 & 0.4216 \\
USERCOST & 1.0503 & 0.422 & 0.5214 & 0.7704 \\
\hline
\end{tabular}

